\title{
INTENSITY OF SOIL CONTAMINATION IN INDUSTRIAL CENTERS OF KAZAKHSTAN
}

\author{
Amanzhol Iztileu, Olga Grebeneva, Maral Otarbayeva, Nina Zhanbasinova, Ekaterina Ivashina, \\ Bekbol Duisenbekov, National Center of Labour Hygiene and Occupational Diseases Ministry of \\ Healthcare of the Republic of Kazakhstan, ncgtpz@gmail.com.kz
}

For Kazakhstan, with its vast territory, the problem of disposal of solid waste from metallurgical, energy and petrochemical industries is becoming more acute. Failure to comply with hygiene requirements for the placement and operation of landfills increases the area of contaminated land and could become a threat to the public of environmental safety of industrial centers. The aim of the study was to evaluate the soil contamination in the towns and cities of Kazakhstan and the allocation of areas of risk to public health. The content of heavy metals in the soil (manganese, zinc, copper, cobalt, nickel, lead, cadmium, mercury, selenium, tin, arsenic, vanadium) were determined by atomic absorption spectrometer MGA-915M. Evaluation of the results was performed with respect to the MPC substances in the soil, the toxicity of the components. Summarized metal soil pollution index (IZ) was obtained by the sum of the rate of excess metal concentration above the level of its world-Clark. To assess the different risk residence zones scale with 5 levels of purity up to 2 - very clean, 2.8 net, 8-16 acceptable, 16-32 moderately dangerous, dangerous 32-128 was chosen. We developed the original software product using GIS technology to provide environmental information on an electronic map of the city in the form of color patches (polygons), matching levels summarized indicator of soil contamination. Found that the most contaminated soil were village Glubokoe where pollution reached dangerous or extremely dangerous levels, Aktau and Zhanaozen in which moderately hazardous contamination was detected throughout; Ust-Kamenogorsk and village Sholakkorgan where moderately hazardous contamination was noted in the fourth part of the urban area. The most common heavy metal toxicity 1-2 class that exceeded MCL in soils, were lead, copper and zinc, and in village Glubokoe - chromium and arsenic, in Aktau - cadmium. Visualization of environmental pollution in some urban areas puts into the hands of environmentalists a new tool in the analysis of environmental health issues to reduce the carcinogenic and mutagenic effects of soil contamination with heavy metals. The mapping results of soil contamination will contribute earmarking local authorities to carry out administrative measures to optimize the environment in the industrial centers.

UDC Number: 614.7, DOI: 10.12955/cbup.2013.60

Keywords: GIS Technologies, ecology, soil contamination, industrial centers

\section{Introduction}

The Decree of the President of the Republic of Kazakhstan No. 922 introduced a Strategic Development Plan of the Republic of Kazakhstan till 2020 (2010). The Plan aims at transformation of the Republic into one of the safest and most stable countries in the world. The plan was to focus on 
resolution of environmental problems, increasing the responsibility of nature users to decrease the emissions into the environment. The plan was to adapt waste processing methods (Baekenova, 2011). But the growth in Kazakhstan is accompanied by the exacerbation of hygiene and environment concerns. There are concerns about the recycling and disposal of solid waste. In 2010 the volume of waste generated in Kazakhstan was more than 900 million tons of which $99.4 \%$ was industrial waste. Only $19.9 \%$ of the waste has been recycled and the remaining solid emissions (79.9\%) are located in controlled dumps. Majority of the settlements does not fully meet the hygiene requirements for the disposal. The operations regarding polygons for waste storage are not up to the standard procedure. Illegal dumps can be found in the towns at large. The contaminated areas have increase rapidly and it could become a threat to the environmental safety of the masses. The largest solid waste accumulation can be found in Kostanay. Kostaney, Karaganda and Pavlodar are the most contaminated areas. The largest accumulation of waste (about $44.9 \%$ ) can be found in Kostanay. Koraganda and Pavlodar have $55.2 \%$ and $23.3 \%$ of the solid wastes, respectively. The major sources of pollution are emissions of carbon, mining, ferrous and non-ferrous metals and energy companies.

The development of hygienically sound environment in industrial areas is difficult without the common methodology for the Republic represented by health and environmental information on the maps of cities and towns. Modern information technology, based on Geographic Information Systems (GIS) offered by specialists from different countries, allows for electronic maps to represent different climatic processes (Semenov et al., 2010), air pollution, water, surface water or soil (Dubovoi et al., 2012; Tikunov, 1997). It reflects the different demographic characteristics (Gabdrakhmanov, 2012) and highlights areas of different risk policies (Grebenyuk et al., 2012). GIS technologies analyses the contamination of soil. These techniques examine the component-wise contamination of soil showing severity of ecological status of the towns, multiple zones, and areas (Shmoilova, 2006). In constructing maps attached to the topographic base, graphical solution of allocation areas of zoning are often presented in the form of colored fields or landfills (Kurolap et al., 2006; 2010). The metrological comparability of heterogeneous data is necessary for modeling of polluted fields in modern cities and towns (Gubaidullin, 2003; 2006). Aim of the present study was to assess soil contamination of residential areas in towns and cities of Kazakhstan in the warmer months to highlight the areas with different risks living for the population.

\section{Materials and methods}

Modeling the accumulation of heavy metals in soil and the selection of zones with different environmental risk of residential zone was conducted by statistical processing of the expected levels of contamination on the 1500-1800 residential locations in 12 cities and towns. Contaminant levels in them were determined by extrapolation and interpolation of the data based on triangles Delano, where mathematical implementation of 3-dimensional response on the two-dimensional surface of the map was made by triangulation. The number and location of these points were obtained in specially developed software for the visualization of environmental data. The starting point for extrapolation and interpolation data were the results of measurements at the points of intersection of regular grids with a side of $1000 \mathrm{~m}$ or $500 \mathrm{~m}$ imposed on electronic maps of cities and towns, which fell on residential areas. Scaling and conjunction of maps to coordinate geophysical grids (longitude and latitude) were based on MapInfo. All hygiene studies to determine the heavy metals in the soil in the summer were conducted in these selected points. We used a database collected by laboratories of Industrial Hygiene and Toxicology, according to the thesaurus, which was designed by us according to our original program (Battakova et al., 2011). So, the territory of Schuchinsk was chosen with 18 
points, for Burabay with 12 points, Temirtau ith 24 points, Ust-Kamenogorsk with 36 points, Glubokoe with 14 points, Taraz with 33 points, Sozak with 16 points, Sholakkorgan with 16 points, Aktau with 27 points, Zhanaozen with 22 points, Ekibastuz with 25 points, Solnechnyi with 13 points.

The choice of cities and towns, for the analysis of the environmental situation in the Republic of Kazakhstan, has been defined by features concentrations of various industries in them. In Temirtau there are located enterprises of ferrous metallurgy. The enterprises of non-ferrous metallurgy are situated in in the city Ust-Kamenogorsk and settlement Glubokoe. The enterprises of chemical industury are located in Taraz. Enterprises of uranium mining and enrichment are found in s.Sozak and s.Sholakkorgan. Aktau and Zhanaozen is hub of oil and gas companies. There are energy enterprises in Ekibastuz city and Solnechnyi. Buraby is selected as a control area for comparing levels of environmental pollution. Burabay is located in the northern part of Kazakhstan at the State National Natural Park.

Soil sampling was carried out according to GOST 17.4.4.02-84 "Soil samples for chemical analysis". Point soil samples (at least 5) were collected with a spatula on a one-off test areas from one horizon of $5-20 \mathrm{~cm}$ by the envelope of which were combined by mixing the sample (weight not less than $1 \mathrm{~kg}$ ) and transported to the laboratory. They were dried to air-dry state. The sample preparation was conducted. The content of heavy metals in the soil (manganese, zinc, copper, cobalt, nickel, lead, cadmium, mercury, selenium, tin, arsenic, vanadium) were determined by atomic absorption spectrometer MGA-915M (Russia, 2004). The main variable of soil survey was the concentration of metals in $\mathrm{mg} / \mathrm{kg}$. Evaluation of the results was performed with respect to the MPC substances in the soil, the toxicity of all the components in SanPiN 2.1.7, and the "Environmental and hygienic parameters characterizing the degree of toxicity of the substance - components of waste", GOST 30774-2001 "Passport dangerous waste".

The metal soil pollution index (IZ) was obtained by the sum of the rate of excess metal concentration above the level of its world Clarke (Starostin, 1997). We took into account only those metals whose concentrations in the residential area exceeded the MPC. The metal content in the soil settlements determined by certified methods for 3 days, every 6 hours (June 2010 - June 2011). The total number of samples for each substance was more than 2555 measurements.

Displaying of pollution in the schematic map of the city was made in the form of color patches (polygons), corresponding to the set levels of summary indicator of soil contamination IZ (Goncharuk, 2006). To assess the different risk zones residence was chosen scale with 5 levels of purity (Mikhailova \& Tomskih, 2012): up to 2 - very clean, 2-8 clean 8-16 permissible, 16-32 moderately dangerous, and 32-128 dangerous.

Quantitative variables were tested for normal distribution. The arithmetic mean, error of the mean and $95 \%$ confidence interval was estimated for normally distributed quantitative variables. A level difference of contamination between cities and control areas was identified by parametric statistics. The only source of contamination, in the control area in the absence of an active man-made activity is the movement of vehicles. Monitoring of soil in Shuchinsk, in the summer, revealed permissible level of metal pollution. The presence of heavy metals above the MPC was noted only for $16.3 \%$ of the samples. A high content of chromium, copper, nickel and zinc was noted. On the territory of Borovoe settlement the level of soil contamination with metal on average was 5.1 units. Thus, it was regarded as a clean soil. But in all the samples increased levels of chromium, copper, nickel, zinc, cobalt was revealed. High levels of lead and manganes was found in every fifth sample. 


\section{Research results}

Continuous operation of facilities of ferrous metallurgy and energy in Temirtau city defined high amplitude of oscillation of summary index of soil pollution from 1.4 units to 41.5 units. In some parts of territory (7.3\%) the level of soil contamination was assessed as permissible, and in $1.2 \%$ of the area is dangerous, but in the main residential area the soil was clean. Polymetallic pollution of the soil in that part of town, which is adjacent to the sanitary protection zones of industrial enterprises, is defined by increased level of 3 metals: lead, copper, and nickel.

Summary index of soil pollution by metals, in Ust-Kamenogorsk, in the summer is characterized by large fluctuations: from 1 unit to 145 units due to the half-century of operation of ferrous metallurgy facilities. So the area of the city with clean soil is not more than $50 \%$ with a permissible $25 \%$ of heavy metal contamination level. About $25 \%$ of the city area are identified as zones moderately hazardous and $8.3 \%$ of the area are found to be hazardous with high risk of contamination (Figure 1). The most unfavorable situation, on the content of metals in the soil, occurs in the central and north-eastern part of the city. Major industrial projects are located in these areas. The metals polluting the soil of the city are lead and zinc. These metal are found in all soil samples.

Figure 1: Zoning of the territory of Ust-Kamenogorsk on summary index of soil pollution with metals

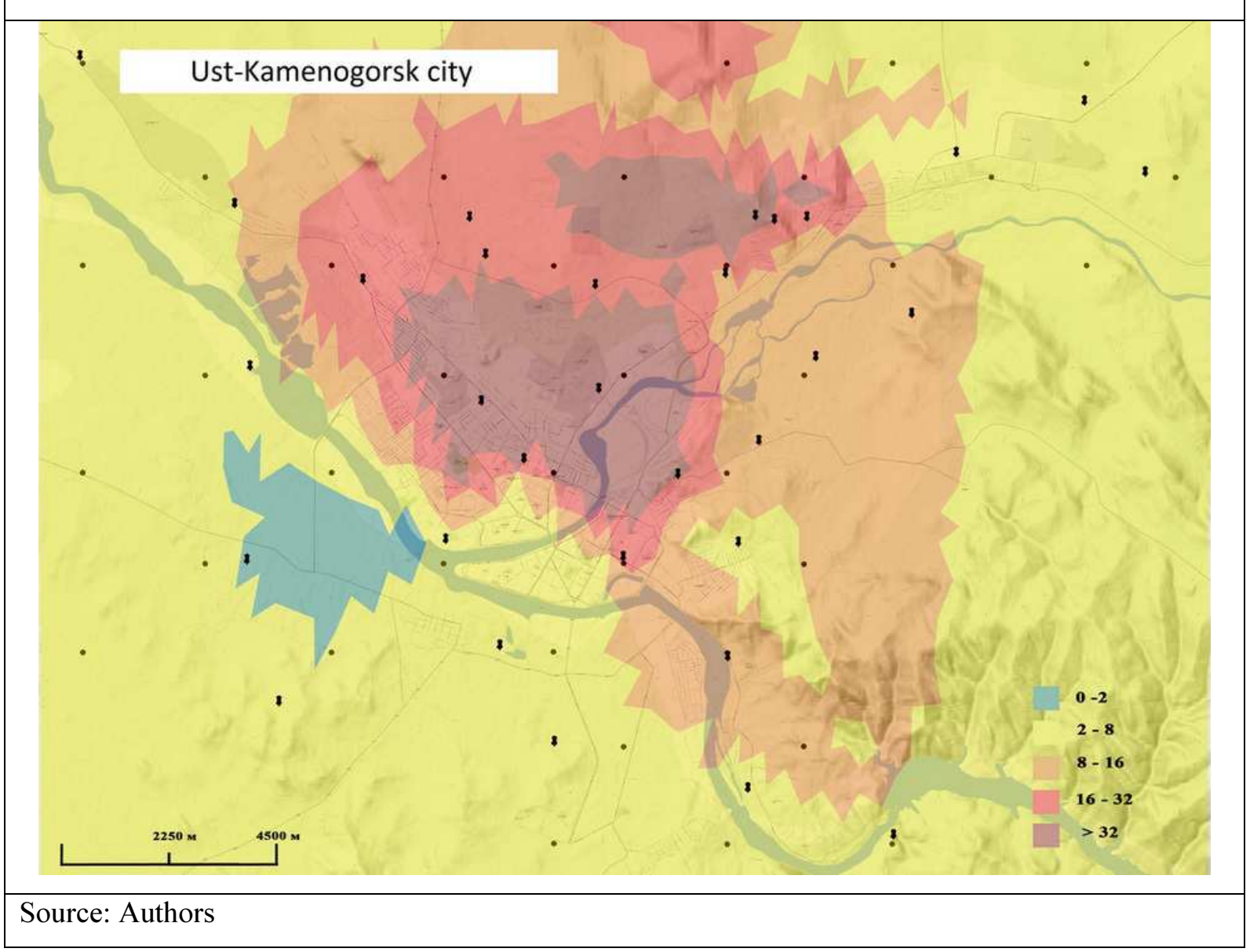

The highest level of soil contamination with metals, in summer, was recorded in the village Glubokoye. The metal contamination was at the dangerous level of the average value of 102 units. The summary indicator of metal contamination of soil ranged from 4 to 237 units in different parts of 
village on the map. Different parts of the village on the map are visually apparent formation of zones with valid or moderately dangerous pollution by $16 \%$. The areas with dangerous levels of heavy metal contamination level of $42 \%$ and with extremely dangerous contamination for $42 \%$ of the village are mentioned in the figure. The soil, throughout the township, had an increased content of copper, zinc, chromium, lead, and half of samples recorded arsenic, antimony, manganese above the MPC level.

Throughout the territory of Taraz city the level soil contamination with metals was very low, although a small part of the north of the city high concentrations of lead, zinc and copper characterize soil contamination metals as permissible.

In the summer, on the territory of Sozak village, soil with moderate level of heavy metals was found in the north-western part of the village. In the south-eastern and central part of the village land was clean. The territory of Sholakkorgan village, with the summary indicator of metal contamination in the soil averaged 23 units, was regarded as moderately hazardous. The two areas of the village were found to have hazardous pollution; the north-east and south-west of the village. In most parts of the village, soil pollution was assessed as acceptable. The pollution of the soil on the outskirts of the village was described as acceptable.

On the territory of Aktau city the summary metal soil pollution index was 20.3 units. It swings from 16 units up to 32 units measured soil contamination throughout and the city contamination level was described as moderately hazardous. The most unfavorable situation on the content of metals in the soil took place in the south-western part of the city. Polymetallic soil pollution of the residential part of the city was determined by increased levels of cadmium, lead and selenium. Metal contamination of soil throughout the Zhanaozen was assessed as moderately hazardous.

The study conclude Ekibastuz city having extremely low content of heavy metals in the soil. Unfavorable situation, in the summer, took place only in the western and north-eastern parts of the city. A small part of the sample reported a slight increase above the maximum permissible concentration of zinc and lead in these parts of the city. Contamination of soil metals in village Solnechnyi, a neighboring village of Ekibastuz, $85 \%$ of the samples were characterized as permissible and $15 \%$ as moderately dangerous due to the intensive exploitation of industrial energy facilities in summer.

Thus, the use of the developed program for the visualization of environmental pollution allowed revealing the part of urban areas with high levels of soil contamination with heavy metals. The most contaminated soil in Glubokoe, where $84 \%$ of the level of pollution reached at dangerous or extremely dangerous levels. In Aktau and Zhana Ozen moderately dangerous pollution is detected throughout. In Ust-Kamenogorsk and Sholakkorgan dangerous contamination level was observed in the fourth part of the urban area. The most common heavy metal toxicity 1-2 class that exceeded MPC soils tenfold was lead, copper and zinc. In Glubokoe, it is chromium and arsenic. In Aktau it is cadmium. The presence of heavy metals in the soil was typical for Taraz and Ekibastuz, Sozak.

\section{Discussion}

Soil hygiene, in modern cities, is still neglected. Its importance as one of the main systems of the biosphere (air, water, soil) and biological factors of the environment is essential (Bakach, 1980). It is known that the flow of toxic substances in the human body is usually on a complex system: the soil plant-human or soil - plant - animal - human, soil - water - human or land - air - human. Exposure to 
certain chemicals, especially heavy metals, can lead to detrimental effects on human health as carcinogenic, teratogenic and mutagenic effects. It may adversely affect the reproductive, endocrine, immune and nervous systems (Demidova, 2010). Industrial emissions of air pollutants have a huge impact on the levels of soil contamination. These pollutants are deposited near the sources of pollution and are accumulated in the surface layers of soil. These pollutants cause rapid anthropogenic transformation of surface of the soil (Rachmanin et al., 2007).

Soil pollution, by emissions of stationary (large industrial enterprises) or non-stationary sources (vehicles), depends on the sources of pollution, meteorological and climatic regions, geochemical factors and landscape conditions. Since heavy metals and products of combustion and emissions of metallurgical industry are traditionally found in various combinations. The effect of the nature surrounding the sources of pollution is more powerful than expected on the basis of the concentration of the individual parts (Druzhinin et al., 2011).

All of the above discussion leaves no doubt that the use of a new program for visualization of soil pollution with heavy metals in urban areas puts into the hands of ecologists a new tool for the analysis of issues of medical ecology. Identifying high-risk areas of the population residence in a number of cities and towns in Kazakhstan may be used in the development of environmental protection measures. The implementation of technologies for processing solid waste and taken into account in the allocation of storage would be useful in the administration and architectural planning organizations in the construction industry. In the industrial cities of Kazakhstan monitoring and implementation of more active management activities in areas of high risk policies will preserve health and prolong the life of the inhabitants.

\section{References}

Baekenova, M. (2011). Nacionalnyj otchet Sostojanije okruzhajushchej sredy v 2010 [National report State of Environment in 2010]. Almaty, Kazakhstan: RSE "KazNIIEK" MEP RK.

Bakach, T. (1980). Ochrana okruzhajushchej sredy [Environmental protection]. (p. 216). Moscow, Russia: Medicine.

Battakova, J. (2011). Informacionno-kartograficheskaja sistema dlja sbora i vizualizacii ekhologicheskikh dannych [Information and mapping system for the collection and visualization of environmental data]. Kazakhstan, 972.

Demidova, Z. N. (2010). Technogennoje regulirovanije v oblasti bezopasnoti khimicheskoj produkcii [Man-induced regulation of the safety of chemical products]. Ekologija i promyshlennost Kazakhstana [Environment and Industry of Kazakhstan], 1 (25), 56.

Druzhinin, P. V., Novikov, L. F. \& Lysikov, U.A. (2011). Toksicheskaja opasnost dlja organizma cheloveka [The toxic hazard to the human body]. Retrieved April 13, 2011, from http://on-linewellness.com/view_post.php?id=115

Dubovoi, I. I. (2012). Primenenije GIS - tekhnologij dlja mediko-ekologiczheskovo zonirovanija territorii krupnovo goroda [The use of GIS technology to medical and ecological zoning of the big city]. ArcReview, 1. Retrieved from www.dataplus.ru / ARCREV

Gabdrakhmanov, N. (2012). Razrabotka i vnedrejije Mediko-demograficheskoj geoinformacionnoj sistemi Respubliki Tatarstan. [Development and introduction of Medical and demographical geo- 
information system of Republic of Tatarstan]. ArcReview, 1. Retrieved from www.dataplus.ru/ARCREV/Number_60/

Goncharuk, E. (2012). Kommunalnaja gigiena [Communal hygiene]. Kiev, Ukraine: Health. PMCid:PMC3444014

Grebenuk, A. N. (2012). Ispolzovanije podkhodov medinskoj geografii pri ekhologicheskoj ocenke krupnovo megapolisa [Using the approach of medical geography in the environmental assessment of a major metropolis]. ArcReview, 1 (60). Retrieved from www.dataplus.ru/ARCREV/Number_60/

Gubaidullin, M. (2003). Geoekkologicheskaja ocenka i prognoz sostojanija territorii pri osvojenii mineralno-syrjevykh resursov Evropejskovo Severa Rossiji [Geo-ecological assessment and forecast of the area during the development of the mineral resources of the European North of Russia]. Perm, Russia: Science. PMid:12918195 PMCid:PMC3301652

Gubaidullin, M. (2006). Ekhologicheskij monitoring neftegazodobyvajushchikh objektov [Environmental monitoring of oil and gas facilities]. Arkhangelsk, Russia: Arkhangelsk Astrakhan State Technical University. PMid:17396579

Mikhailova, L. A. \& Tomskih, E. S. (2012). Uchebnoje posobije po kummunalnoj gigiene [The manual on environmental sanitation]. Chita, Russia: IPC CHGMA.

Rakhmanin, Y. (2007). Sovremennyje napravlenija metodologii ocenki riska [Modern Trends in risk assessment methodology]. Gigiena i sanitarija [Hygiene and Sanitation], 3.

Semen, K., Mamchik, N. \& Klepikov, O. (2006). Ocenka riska dlja edorovja naselenija pri tekhnogennom zagrjaznenii gorodskoj sredy [Assessment of risk to human health at technogenic pollution of the urban environment]. Voronezh, Russia: Voronezh State University. PMid:17147274

Semen, K., Mamchik, N. \& Klepikov, O. (2010). Integralnaja ocenka kachestva okruzhajushchej sredy naselennych mezd Voronezhskoj oblasti. Mediko-ekhologicheskij atlas Voronezhskoj oblasti. [Integral assessment of the environmental quality of settlements Voronezh region. Medical and ecological atlas of the Voronezh region]. Voronezh, Russia: Resources. PMid:20532252

Semenov, O. E. (2010). GIS - tekhnologija monitoringa i modelirovanija pilnykh bur [GIS technology of monitoring and modeling of dust storms]. Gidrometeorologija i ekologija [Hydrometeorology and Ecology], 3 (8).

Shmoilova, G. (2006). Geoekologicheskoje sostojanije gorodskoj sredy goroda Niznevartovska [Geoecological state of the urban environment in Nizhnevartovsk]. Problemi regionalnoj ekhologii [Problems of regional ecology], 6 (18).

Starostin, V. \& Ignatov, P. (1997). Geologija poleznykh iskopaemykh [Mining geology]. Moscow, Russia: MSU. PMCid:PMC1181148

The Decree of the President of the Republic of Kazakhstan in 2010. (2010). Ukaz Prezidenta Respubliki Kazakhstan ot 1 fevralya 2010 goda № 922 «O Strategicheskom plane razvitiya Respubliki Kazakhstan do 2020 goda» (s izmeneniyami ot 27 avgusta 2012 g.) [Decree of the President of the Republic of Kazakhstan on February 1, 2010 No. 922 "On the Strategic Development Plan of the Republic of Kazakhstan up to 2020" (as amended on 27.08.2012)] Available http://online.zakon.kz/Document/?doc_id=30559730 [Accessed February 10, 2013]

Tikunov, V. (1997). Modelirovanije v kartografii [Modelling in cartography]. Moscow, Russia: Moscow State University. 